\title{
The Development of Innovative CRM E-Commerce: The Case of Blibli.Com
}

\author{
Indra Gamayanto'; Henry Christian² \\ ${ }^{1}$ Information Systems, Faculty of Computer Science, Dian Nuswantoro University \\ Jln. Imam Bonjol No.205-207, Semarang 50131, Indonesia \\ ${ }^{2}$ Atek Foods-suppliers, Jakarta \\ Pasar Glodok Los CDB 202-203, Jakarta Barat 11120, Indonesia \\ 1indra.gamayanto@dsn.dinus.ac.id; ${ }^{2}$ xcoolzy.henrychr@gmail.com
}

Received: $25^{\text {th }}$ October 2017/ Revised: $20^{\text {th }}$ November 2017/ Accepted: $4^{\text {th }}$ Desember 2017

How to Cite: Gamayanto, I., \& Christian, H. (2018). The Development of Innovative CRM E-Commerce:

The Case of Blibli.Com. Binus Business Review, 9(1), 29-38.

https://doi.org/10.21512/bbr.v9i1.4100

\begin{abstract}
This research discussed how e-commerce companies improve its competitiveness in the retail industry in Indonesia through innovative CRM. Blibli.com is one of the largest e-commerce companies in Indonesia that provides customers with innovative services to enhance its competitiveness with other e-commerce companies. This research also aimed to explore the strategies carried out by Blibli.com in developing its CRM. It used the $7 \mathrm{~s}$ stages of McKinsey analytical methodology. The 7s stages of McKinsey was the excellent method of analyzing a company, regarding hard skills (Strategy, Structure, and System) and soft skills (Skill, Staff, and Style). This research finds that Blibli.com is an innovative CRM e-commerce. The analysis confirms that Blibli.com employs good strategies, structure, and system that lead to a competitive company. The company also provides training for its staffs, manages the staff and style properly. As a result, Blibli.com can widen its market, compete effectively with other e-commerce companies, and create a new market to gain big profits in the future.
\end{abstract}

Keywords: Customer Relation Management (CRM), innovation, e-commerce, Blibli.com

\section{INTRODUCTION}

Changed or unchanged is a decision made by people. People always experience some problems that ultimately change the overall pattern of their future like information technology. Technology can change the whole pattern of human life such as the whole pattern of consumptive change.

When e-commerce companies are established, some are successful, and the others fail. This intense competition leads to innovations that make people's lives have positive and unique variations. With so many innovations growing, the question is whether people can survive against it.

Ilieska (2013) suggested in customers' behavior, the person was used as a factor for making marketing strategies and adapted the marketing mix to their needs. This was the only way for a high - grade satisfaction of the customers' needs. In the conditions of the company where the customer was the focus, knowing the customers' needs was an important combination and factors for production and the marketing strategy.

Retail business in Indonesia is still a promising business choice. The growth opportunities are promising viewed from the ratio of retail and population of Indonesia. Until 2012, 1.000 .000 new residents have been served by 50 retailers including supermarkets, hypermarkets, and minimarkets. The ratio is between the numbers of retail and the lowest number of Indonesians in Asia Pacific. It is a promising opportunity to make Indonesia as one of the countries in international class retailers (Tan, 2013).

The growth of retail in Indonesia is also good. In 2007, the number of the retail outlets was 10.365 . Then, in 2011, the retail outlets in Indonesia grew to 18.152 outlets. 
According to Asosiasi Pengusaha Ritel Indonesia (APRINDO - Association of Indonesian Retail Companies), retail business grows about $10-15 \%$ per year (Soliha, 2008). The largest revenue contribution is from hypermarket, followed by minimarket and supermarket. The retail business can be defined as all activities that involve the sale of goods and services directly to the end consumer for personal use or meet consumers' needs and not for business purposes. Retail is not just a real-life selling activity, but it can be broader. The activity of providing services can also be referred to as a part of the retail activity, so it is necessary to distinguish between retailers who focus on merchandise, or on the services. The difference is only when there is a percentage of service provision compared to the purchase of goods products.

The growth of retail business causes intense competition among retailers. Various strategies are used to gain new customers and retain old customers. Price is no longer the main weapon of modern retail, but it can be better service to customers. One of the strategies is Customer Relationship Management (CRM). CRM is a process of several stages consisting of identification, acquisition, retention, and customer development. It contributes greatly to the company by focusing its strategy on maintaining customer relationships effectively and efficiently so that the relationship becomes a profitable lifetime relationship. CRM is also a type of retail company management. It specifically considers the relationship between the company and its customers to increasee the value of the company. Thus, the main goal of CRM is to promote a long-term growth and profitability of the company through a better understanding of customer habits (Tan, 2013)

The implementation of good CRM will create customer loyalty and word of mouth. CRM developed in the long term can deliver the value required by customers so that there are satisfaction and loyalty. Loyal customers will continue to make purchases at the same retail company. Moreover, satisfied customers are not only loyal but also tell the positive experience to the parties around. Information about positive experiences received from word of mouth can influence others to become the customers too. Moreover, CRM provides benefits for achieving success in delivering higher value to customers compared to competing retail companies. It implies that CRM brings competitive advantage to retailers for the long term or sustainable. CRM can be used to achieve the sustainable advantage with its ability to retain existing customers through the power of established emotional connections. When the power of emotional connection can be realized, the customer will have a small chance of disloyalty to the retail company. The crucial role of CRM for retail companies will be the background for developing the discussion in this research. Retail companies in Indonesia are expected to implement CRM well in developing operational activities so that it can survive in intense competition. This is because the competitors are not only from within the country, but there are also many foreign retail companies. Retail companies in Indonesia should implement CRM as a competitive strategy to create customer loyalty. It is essential to face the intense competition (Tan, 2013).

Blibli.com is one of the largest e-commerce companies in Indonesia. It provides many innovations, so the CRM level is very good. Besides that, the company is a brand that can be trusted, so this increases the level of consumer confidence in shopping in Blibli. com. Trust is one of the main factors in increasing the profit of the company that Blibli.com does many in serving the community in Indonesia (Tutupary \& Aldianto, 2014)

Blibli.com was established on July 25th, 2011 by PT Global Digital Niaga (GDN). In 2012, Blibli.com won The Best E-Commerce award from Gadget Award 2012. This award was received by Blibli.com because the consumer's appreciation of the consistency of Blibli.com in presenting the latest gadgets, attractive promos, and creative communication program. The award was expected to encourage Blibli.com to make online shopping as the main destination of the Indonesians to get products of a smart and dynamic modern lifestyle. Therefore, CRM must be properly understood as it can providee marketing strategy in establishing long-term customer relationships and profitability (Wardhana, 2016)

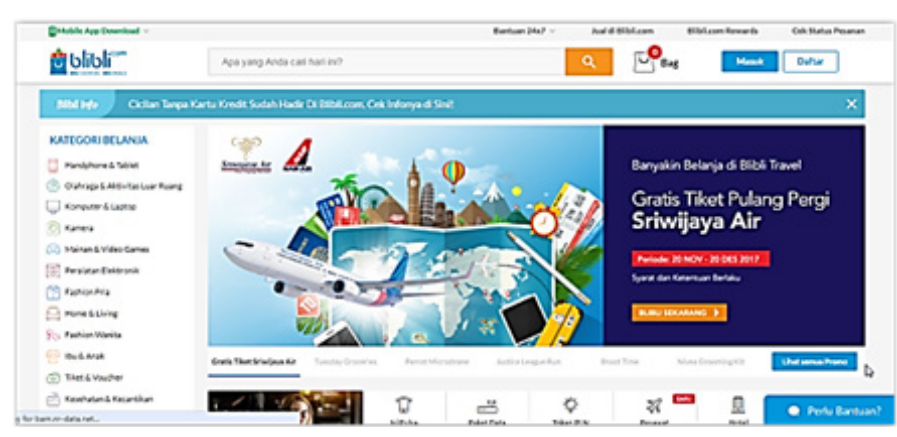

Figure 1 Blibli.com Website

In Figure 1, it shows the website owned by Blibli. com which already has the convenience for customers to shop online. As the growth of e-commerce business is an organic and non-organic business, the growth is sourced from within and beyond. This separation becomes increasingly blurred today. Organic growth in e-commerce means building what the company already has. It is usually the easiest and fastest (Lundberg, 2012). However, the company does not need to do that. It should move from one product, find the best solution, apply the sales model to generate huge revenue or high profits, make a difference to the offer, and engage the customer deeper. Companies should have done those. For example, it can be when the company starts offering guarantees-based financing. Similarly, e-commerce business should not only offer a guarantee, but it should also provide other services that may be profitable. 
With the increasing competition between e-commerce companies, innovation must be done by Blibli.com. The main issues that must be done for innovation development include several points. First, it is whether CRM and e-commerce strategy by Blibli.com still reach the market share. Second, it is whether the infrastructure owned by Blibli.com is ready or not. These issues should be seen as an opportunity to face increasingly competitive competition. Innovation in e-commerce business strategy, CRM, and innovative product become an indispensable thing in making Blibli.com larger and the winner of the global e-commerce market.

\section{METHODS}

The data obtained for this research comes from Blibli.com website by learning what Blibli.com has done on the website; how to make consumers interested in buying; and how the service is done to satisfy the consumer. The data can be viewed in Blibli.com website. Then, the data are analyzed by using the 7 stages of McKinsey. This method will tell what Blibli.com has done to face the global competition of e-commerce today.

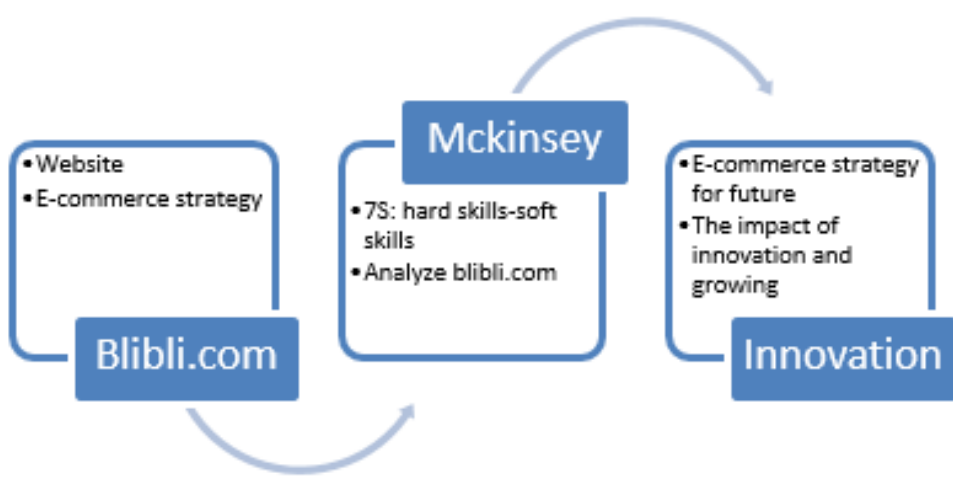

Figure 2 Analysis Process in Blibli.com

Figure 2 shows the process of generating e-commerce and innovation. Blibli.com is analyzed by using 7 stages of Mckinsey. It is a method of knowing seven important things that are divided into two parts: hard skills, and soft skills.

The hard skills consist of three elements: Strategy, Structure, and System. In Strategy, a plan is designed to maintain and build competitive advantage in competition. The company's strategy is intended to enable the organization to have clear and decisive direction on the way to achieve the goals and objectives. Without a clear strategy, every organization will be in a condition like a ship that sails without ever knowing where it will dock. In business, the strategy reflects an accurate review of the business environment, especially current and future activities of competitors. System refers to information systems and technologies developed by the organization that can support existing shared vision. Structure indicates the reflection of shared vision in the company to achieve strategic goals and objectives. Structure that can realize shared vision well will empower organizations to achieve these strategic goals and objectives.

On the soft skills, there are Style, Staff, and Skill. Style is the management and leadership style of the company. It is adopted to facilitate the achievement of shared vision along with the objectives and corporate strategic objectives that have been formulated. Staff is the member of the company that must realize the shared vision of the company to achieve the objectives and strategic objective. Meanwhile, Skill is the actual skills and competence of all members of the company. It must be able to realize the shared vision along with the goals and strategic objectives. The seven stages can be seen in Figure 3.

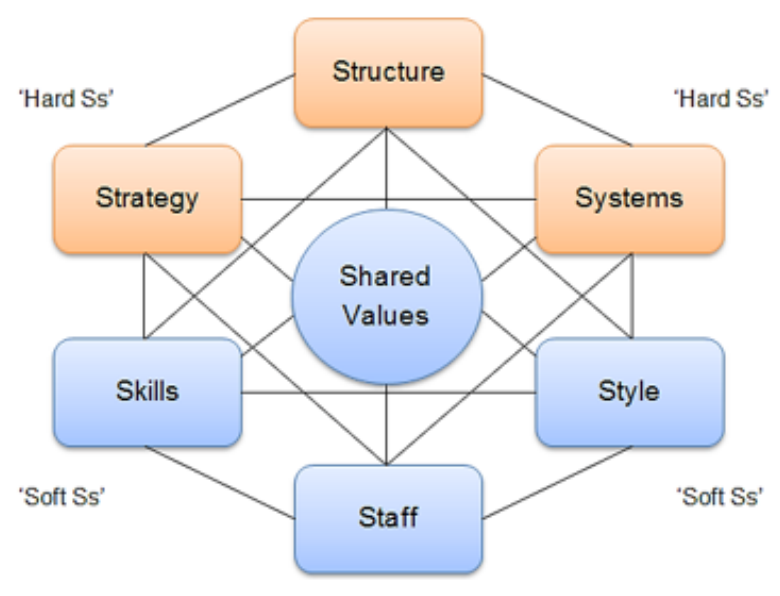

Figure 3 The 7 Stages of McKinsey

(Source: Ravanfar, 2015)

\section{RESULTS AND DISCUSSIONS}

The 7S's McKinsey method has 7 important sections that are divided into 2 important parts: hard skills and soft skills, and in the middle of those two important things are shared values. The first discussion is about shared values, which then continue on the hard skills and soft skills.

Shared vision underlies the establishment of the company. The company's vision is an indication for all members to grow and develop, while developing an organizational vision. It is necessary to pay attention to some criteria that are short and easy to remember, and created by consensus. It also has influence and challenge for people to achieve that vision, provides direction, focuses on organization and management, and attracts employees, customers, and stakeholders. In short, it is a description of the desired ideal state and level of service, product quality, and desired cost in the future which should be up to date. 
Furthermore, shared vision or Shared Values in Blibli.com is a social e-commerce developed with a vision to provide a safe, convenient, and liberating online shopping experience with the spirit of Bring A Better Life, Keep It Simple, Create Fun Experience, and Set Free. Bring A Better Life is a spirit of having: (a) Safe and secure shopping, Blibli.com works with trusted banking partners, and all transactions are secured by VeriSign certification and credit card fraud detection system; (b) Original products, all products present at Blibli.com are original products. Blibli. com does not sell artificial products or black market items; (c) Enrichment from experts, Blibli.com also presents informative and useful articles, and product reviews from experts to help customers to make smart and precise decisions in shopping. Keep It Simple is a spirit with: (a) Intuitive design, Blibli.com is designed with a clean and simple look, and a neat product categorization system that suits customers' activities and lifestyle. Thus, all products can be searched and found easily; (b) Quick check out, the transaction process at Blibli.com is done with three easy steps. There are adding to cart, selecting the shipping and payment method, and completing the transaction according to the payment option. Create Fun Experience is with: (a) fun deals, shopping at Blibli.com is more fun and exciting with weekly deals featuring different weekly offers, reward systems, and special shopping coupons that people can use to get a discount; (b) personalized shopping and sharing experience, shopping is a more exciting and personal activity if it is done with friends and family.

Thus, Blibli.com offers personalized ease and sharing of shopping experience through My Blibli features, such as personal shopping profile, wish list, points, and bonuses special shopping, freedom of sharing favorite products through various social media sites; Set Free is a spirit having (a) anytime anywhere shopping, Blibli.com also comes in the form of the Facebook store and Mobile store which allow people to shop anywhere and anytime with media for the needs and situation; (b) flexible payment method, Blibli.com offers a variety of payment methods. It ranges from master credit cards and visa, Klik BCA, and transfers to BCA and Bank Mandiri accounts. At Blibli.com, customers can also pay with installment facility with $0 \%$; (c) full-service customer center, all questions, feedback, and suggestions will be served professionally and dedicated by the customer service center (Wang et al., 2017; Wardhana, 2016).

On the hard skills (Strategy, System, and Structure), the researchers will see the section on cooperation with Blibli.com. Affiliate programs have a very practical and innovative way of working.

Figure 4 shows the work process in affiliates. Blibli.com offers convenience for people who want to affiliate and develop their business. In the sale section on Blibli.com, it has advantages such as (a) product and packaging, Blibli.com has been trusted by various big brands. As one of the pioneers of an online shopping mall, Blibli.com has been trusted by well- known brand as official partners such as Nike and NBA Store. It also provides $100 \%$ product insurance and free shipping. The shipping costs will be paid by Blibli.com with coverage throughout Indonesia). (b) Other facilities, it offers free packaging as Blibli.com has provided ten types of packaging for free, and free marketing exposure. (b) Merchant support, merchant care service (Monday - Friday, 08:00 - 20:00 WIB) is ready to assist with live chat service, e-mail, and telephone. With Merchant Tools Application (MTA), it can upload products, change prices and stock wherever and whenever. The merchants also get free training for every Tuesday and Thursday at 10:00 - 12:00 pm at the office Blibli.
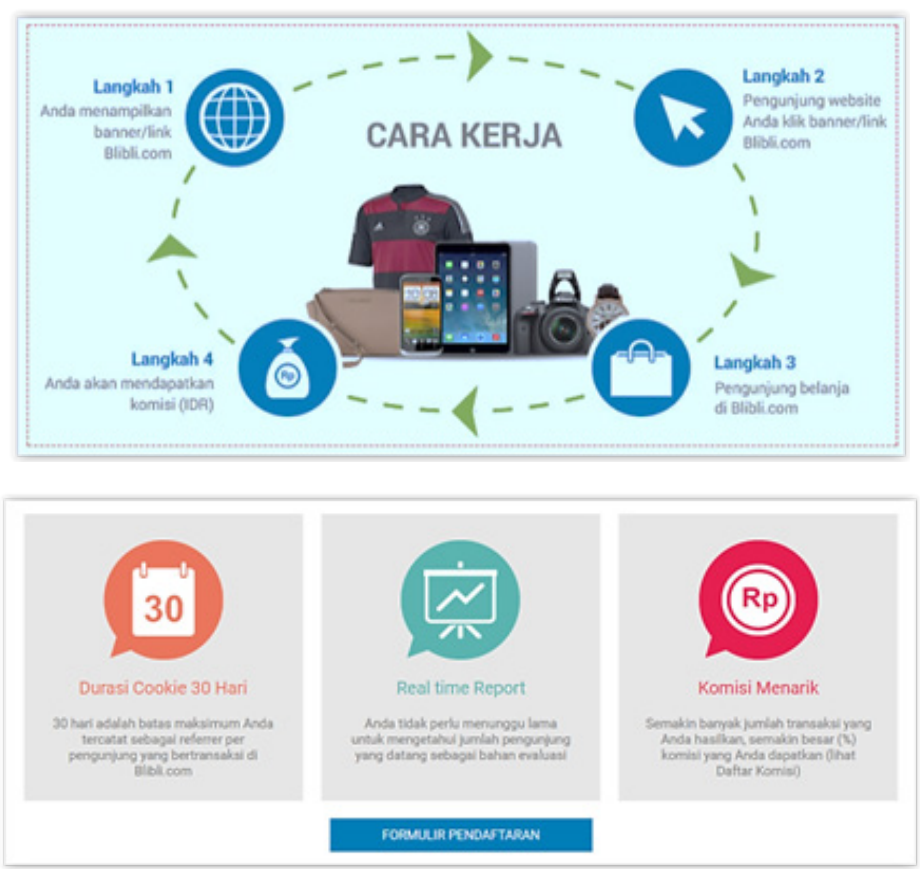

Figure 4 How affiliate program works Blibli.com and reasons to join

The process of becoming a merchant is as follows. First, the merchants need to register online. It can be done online at https://www.Blibli. com/pages/merchant-corner. Then, Blibli.com will call the potential merchant to verify data. Second, the merchants upload product. Once registered as merchants of Blibli.com, they will get an invitation to attend Merchant Tools Applications (MTA) training in Blibli.com office. Merchants who are outside Jakarta will get the user tutorial video. In MTA the product description and specification details and product image are available. Third, when the merchants get the order from Blibli.com customer, they will get notification via email and SMS so that order can be done. After fulfilling orders in MTA, the product must be packed immediately. Packaging must be done properly and correctly so that the product remains intact when it comes to customers. Fourth, the payment report will appear on MTA report. The payment will be done once a week. 
Furthermore, there are three strategic factors that must be considered for e-commerce to be developed and sustainable. It includes the increasing opinion and market share on Blibli.com. There are selection, pricing, and sustainability. The selection factor is the ability of the platform to provide variety and quantity of products. Blibli.com has the concept of Business to Consumer (B2C) and attracts brands that want to build online channels. The company also develops warehouses and creates distribution channels or supply chains for the platform. Then, for related pricing, Blibli.com cannot avoid fierce e-commerce business competition. Because of that, it creates collaboration with suppliers and partners such as banks for promotional programs. Sustainability factor is achieved through service. Blibli.com always puts consumers as the main point.

Figure 5 shows the merchant corner. In this site, merchants can register easily. Blibli.com has a reliable B2B program. There are many benefits of joining B2B Blibli.com. First, it provides product rates with a special rate for the company; multiple types of payment like Cash on Delivery (COD); and other conveniences such as the term of payment. Second, With the strength of the logistics team (Blibli Express Service), and support from trusted partner logistics, it is ready to send the order to all over Indonesia. Third, there is after sales service. It is ready to assist the claim if the ordered product has a problem). Fourth, it is original and official guaranteed products. B2B Blibli.com has more than 1,5 million products from trusted brands and merchants, so the quality of its products is guaranteed with an official warranty. Last, there is no minimum order. It serves orders from a piece to order using container.

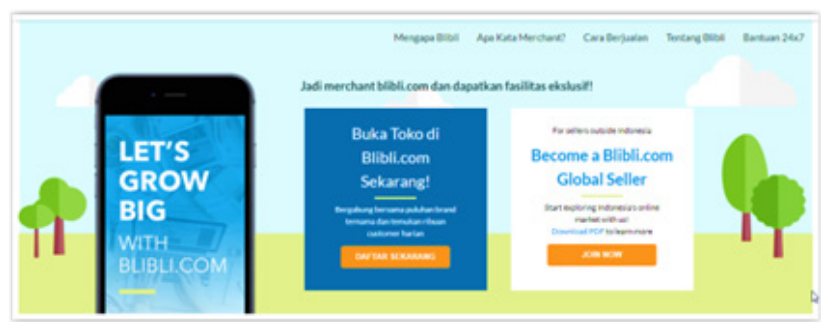

Figure 5 Merchant Corner

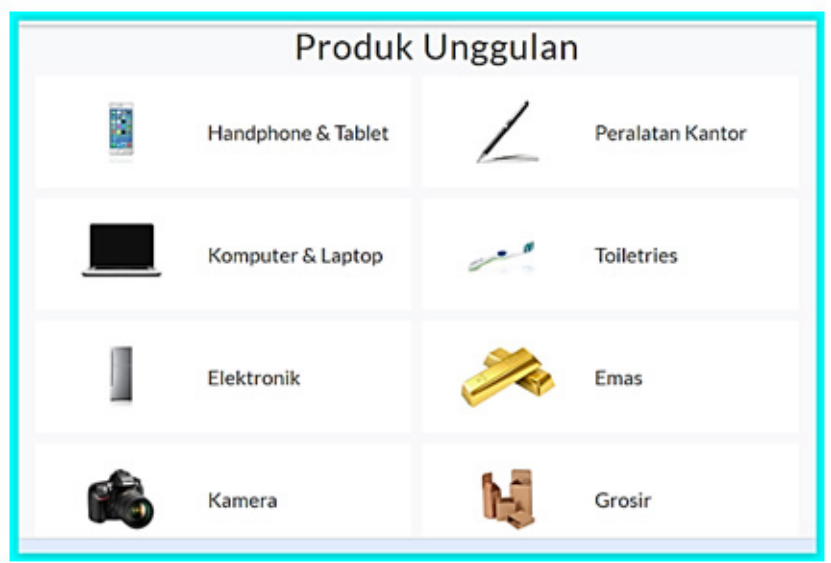

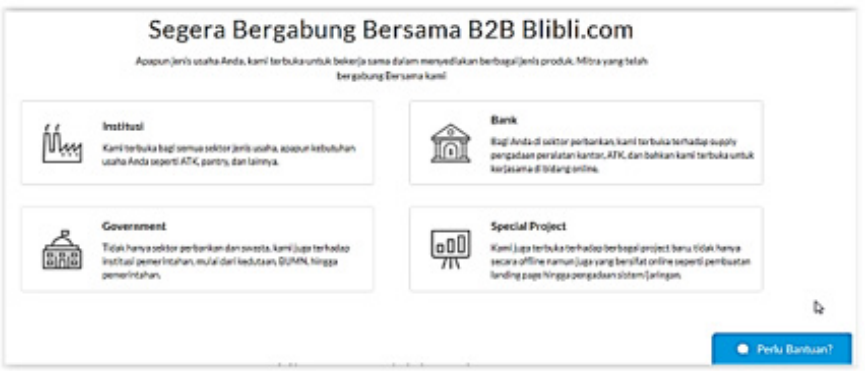

Figure 6 Featured Products and B2B Strategy

Figure 6 shows how Blibli.com creates B2B strategies. Blibli.com performs special programs such as offering partners in developing a business, they will be obtained information about the partners who have joined with Blilbi.com. For some reason, it will invite true creative problem solvers and passionate business builders to empower Indonesia in Blibli.com. It will be through endless opportunities. Everyone is invited to solve real-world problems and makes differences every day for a better life.

On the soft skills (Staff, Skills, and Style), Blibli.com have a great goal in the face of global competition. The Excellence (be an overachiever) is a pitfall history as it has proven itself that only paranoids survive. Serving is focusing on what to give than to receive and be humble. Passionate and Proud are the fuel to accomplish the unimaginable and to be proud of what they build. Employee's Great Place to Work, Bliblioneers build the relationship through open communications that they are from one another and accept each other's imperfections. Customer Focus is on taking care of customers and work backward. The formula of Customer Focus has always been the same: me, team, company, and customers. Teamwork builds a synergy out of trust.

Live Life to the Fullest: (1) Inspiring Workplace is the melting pot of bright talents from world-class multinational technology, agencies, manufacturers, and entrepreneurs. Blibli.com provides opportunities for bright talents to explore diverse perspectives and ideas among others, so it inspires one another in pursuing life purposes. (2) Continuous Learning is a belief that it can only propel people to move forward by constantly open self to new possibilities and solve real challenges. Through series of free open classes, coding class, and photography course, it wants to ensure that talents are constantly empowered in pursuing life purposes. (3) Fun Community is the routine by joining the fun and family-like community such as dance, singing, diving, photography, basketball, badminton, futsal, yoga, Zumba, and many more.

The core strength of Blibli.com is this company develops two things that become its main focus. The company must have comfort so that employees can work and get inspired. On the other hand, the consistent learning should be developed. This attitude 
is an attitude that gives strength to self-development, knowledge, and expertise. Thus, Blibli.com will continue to grow and compete with other companies.

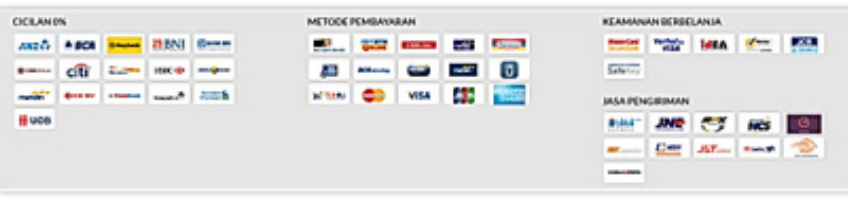

Figure 7 0\% Installments, Payment Method, Security Shopping, and Shipping Service

Figure 7 shows how Blibli.com offers 0\% interest rate installment. It is very necessary to make an e-commerce concept strategy that may be applicable in Blibli.com. There are three basic platforms in the growth of e-commerce. It should not be considered as alternatives, but as an opportunity where an e-commerce company should have important things at every level. The platform is distinguished by the time and effort required to generate significant growth, risk, and outcomes.

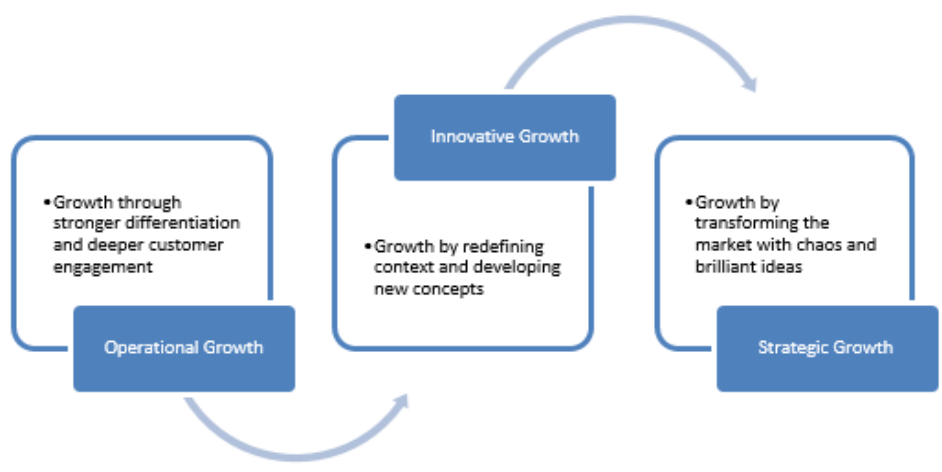

Figure 8 Platform for Growth-Enduring and Profits in E-Commerce Companies

Figure 8 describes three important growths that must be possessed by Blibli.com to face global e-commerce competition. First, in operational growth, it performs better than it already does. It includes: (1) adding-making customers buy more. Blibli.com should be able to add more customers. On the other hand, it may increase corporate profits, but the most important thing is how Blibli.com maximize the CRM. It has to build relationships with customers, so that old customer of Blibli.com can survive. Then, from the recommendations, it will gain new customers who have been through the process of market segmentation and location. (2) Maintaining (maintaining the best customer). Blibli.com, in this case, should be able to retain their best customers or premium customers. These customers are the main capital of Blibli.com in developing the company. The connection will be wider and will be established. If it is possible, premium customers can become investors in the company Blibli.com. (3) Expanding (entering new customer segments). New segments should be established to continue expanding the company. Blibli.com, in this case, must immediately determine a new segmentation strategy, which can expand its market share so that it can compete. (4) Reaching out. It should be broadly formed by making more detailed segments and locations. (5) Global (entry into new geographic markets). This is related to demography. Demography is the research of population density and distribution. In addition to age, education, income, lifestyle, and place of the population, this is the most important in determining segmentation and location. (6) Differentiation (communicate new offerings). Blibli.com should be able to create a more innovative differentiation of service offerings. (7) Downsizing (improve business efficiency). The efficiency needs to be done in increasing profits and reducing waste levels especially the unnecessary cost of Blibli.com.

Second, there is innovative growth. It consists of: (1) discovering new products and services. New products and services must be created by establishing research \& development with the company. (2) Reapplying (create new apps for products and services). Blibli.com can create new applications such as developing Android in its service. It is important to maintain old systems, develop existing old systems, or replace old systems into a new system. (3) Collaboration. Developing solutions with newly committed partners-partners owned by Blibli.com are already meeting the required requirements. However, it needs to be improved even more by working with new partners at the international level. (4) Diversification (launch new enthusiasm for corporate branding). Blibli.com can innovate brand management with international companies that have been successful in raising their brands. Thus, Blibli.com can become a more competitive e-commerce marketplace and can be better known at the international level. (5) Conceptualizing (design a new business model). This new business model can be developed from the thing that already exists. Blibli.com services can be further enhanced by enhancing cooperation with other e-commerce companies. (6) Sharing. Establishing cooperation for various resources can be enhanced at Blibli.com by improving existing human resource capabilities or cooperating with other e-commerce companies to upgrade them. (7) Partnering. The partners owned by Blibli.com must have a strong brand, but it needs to be improved even more in cooperation with the international partner.

Third, it is strategic growth. It includes: (1) establishing a new market in accordance with the vision of Blibli.com. It should fulfill its vision of global competition. If it is necessary, Blibli.com can gradually change its vision to adjust to the growth of global e-commerce market. (2) Focusing on being an expert in a specialized field. The expert in e-commerce is the focus of Blibli.com, but it needs to be emphasized more. This skill should continue to 
be developed by building a wider infrastructure in the market of e-commerce internationally (Anwar, Shah, \& Hasnu, 2016). (3) Expanding (diversify into various categories). Blibli.com, in this case, has implemented a product category strategy appropriately on its website. Moreover, the good service can already be seen and felt directly by consumers. (4) Getting (buy from direct competitors). Blibli.com can also purchase an e-commerce company and combine it with Blibli. com so that it can expand the market. (5) Connecting (find alternative business models). Blibli.com should keep trying to find alternative business models. If the e-commerce business model owned now is lacking, it should be replaced with a better alternative (Madu, 2012). (6) Speculating (create new speculative businesses). Blibli.com can increase the risk by making new speculations such as expanding its location. However, it needs to be cautious as it will have an impact on corporate profits and losses. (7) Going forward (turn a business into a new market). A new market can be determined appropriately, if the company makes segmentation and location clearly.

Collectively these initiatives produce a growth. It is a collection of different initiatives that will generate short-term and long-term growth with varying levels of business and risk. How growth is achieved depending on the e-commerce company, but most can depend on the internal and external side. It depends on what is right for the market and the organization.

Growth is simple. It is how an e-commerce company can use its assets including brands and relationships. Then, the assets are matched with the best market opportunity for that growth which generates profits. Matching assets to opportunities is a creative process. The simplest way is to match the strongest assets with the best opportunity. Then, the company examines how different combinations produce growth innovatively. The best initiatives are formed and evaluated together by forming an initiative portfolio. It is a general operational growth that will produce the fastest results with the least impact (Ilieska, 2013; Lunenburg, 2012).

The e-commerce company wants to show significant growth. Innovative growth takes longer, but it will eventually show a difference. E-commerce companies also want strategic growth and even slower processes, but the results will get the company. Like other managed portfolios, the challenge is to create a balance between "the brainless" and the more strategic "big bets" (Mcfarlane, 2013; Gamayanto \& Esti Nilawati, 2017).

Growth is needed as the important part of strategic planning by showing all initiatives and evaluating its strengths and weaknesses (RamseookMunhurrun, 2010). Only in this way, the portfolio of change exists and only in this way the growth can be managed. The question is who the person is that should manage growth in this business. Because growth is so often seen as output, growth is often left without management or is the responsibility of the CEO or the finance director. Growth requires dedicated management by having people with the best mindset for growth, the closest to market opportunity, and the ability to lead innovation.

The most suitable "growth center" is the marketing and commercial director even though this is a new role in an e-commerce company. It is a role that can combine a focus on sales and marketing, and prices and profits. Then, it can become a champion of growth for all e-commerce businesses. Therefore, e-commerce companies need acceleration.

In an ongoing research and observation to appreciate creativity in e-commerce, there are three important ways to improve the economic value of an e-commerce business and future cash flow. Those are increasing income, reducing risk, and accelerating growth.

Accelerating growth seems clear about working harder, and growth is imminent. However, e-commerce business can only work in line with market rhythm, even if the e-commerce business can affect the market widely. An effectively managed growth portfolio can be accelerated in several ways. There are three platforms as an innovation of the three previous platforms that have been described.

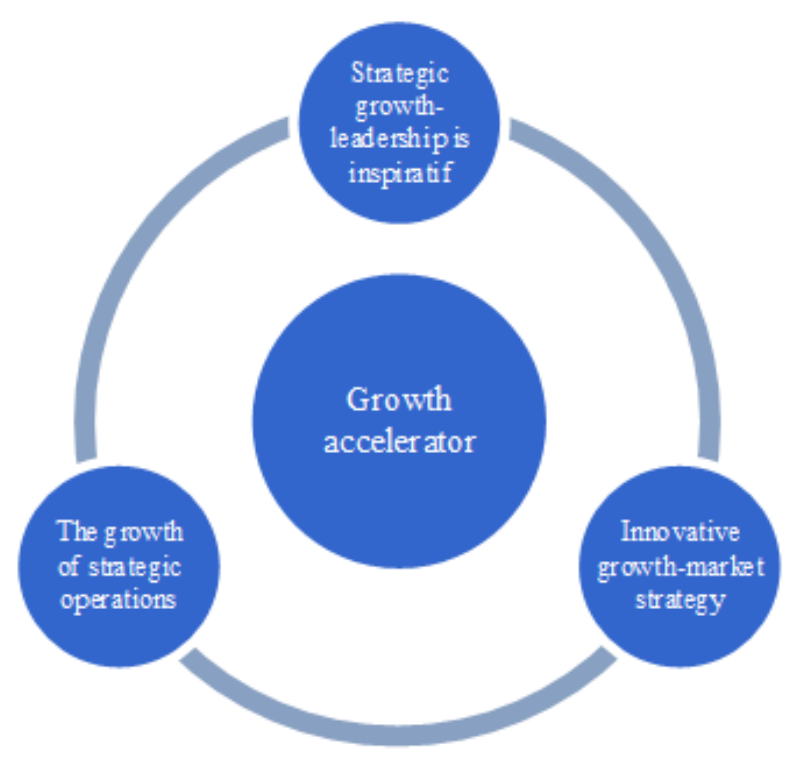

Figure 9 Accelerating the Growth

of E-Commerce Companies through Innovative Inspiration-Strategy Leadership

Figure 9 indicates the inspiration strategy for growth accelerator. It includes: (1) faster decisions. Large and well-known e-commerce companies are slow to grasp opportunities, especially when growth is known only in planning circles. (2) Rapid development. This can reduce the time for new markets or products, processes and systems by coupling, outsourcing activities, in-market trials and strategy evolutions. (3) Market instincts. It has a faster sense of market change and can sense and respond to customer needs, competitors' activities 
and emerging markets (Hossain et al., 2012). (4) Double segmentation. Evaluating potential customers is not only regarding characteristics, motivations, and values, but it is also the consideration of how they will evolve the market penetration strategy. (5) Slipstreaming. It develops innovations so that product and service developments can be launched together with strategic speculation that may take longer to pursue. (6) Internal creativity. This involves people in the pursuit of growth by accepting their ideas and giving them space and responsibility to grow their business. (7) Intelligent engagement. It finds partners who can meet the needs. For example, it is to reach new markets, but from partners that the company can learn more from. (8) Focusing on resources. It focuses on the most important markets and opportunities, and does fewer things better with more resources and profit sharing commitments. (9) The speed of the organization. It develops the process and culture that wants and accepts constant change rather than seeking consistency and equality. (10) Access to capital. By having quicker and easier access to capital when it is needed, the mindset of risk capitalists is ready to invest when they see the right opportunity. Portfolio balance ensures that there is a good balance between strategic and operational initiatives taking place, and investments and resources are appropriately allocated. (11) Dedicated management. It makes the growth of activity can be measured by dedicated responsibilities and resources, focus, and appreciation. Demand for growth will become bigger and faster. When the global e-commerce market is connected, the competition gets intense. When technology makes things fast, and customers become bored faster, companies need to find a more significant and faster growth strategy.

Chris Zook in Unstoppable said over the next few decades, 2 out of 3 companies would face challenges in corporate life by redefining their core business to survive the competition, facing with increasingly fierce global competition, and changing global dynamics, and faster changes. Business leaders would face an uncertain future. Furthermore, executives would realize that they had to make fundamental changes in their core business to spur future growth even as they continued to provide goods and services so their business could survive (Rigby \& Zook, 2002).

The result of the platform innovation is the establishment of location strategy in e-commerce and the formation of more colorful segmentation. It is called colorful segmentation market. About the hot spot, today's competitive market, where growth and price are high, can compete strongly. In the cold place, it has high potential that is not found by most competitor. The white spaces or new opportunities often come from a unified limitation or new technology. Then, the black place is the market of the past, which may be familiar and bring memories, but is experiencing a drastic decline now.

Figure 10 indicates the location of sharing in e-commerce and innovation strategies. With these growing places, e-commerce companies can determine where the best opportunities are, where the competition is, and where it will be. The identification is as follows: (a) hot locations is where requests meet, and all brands attempt to play. For example, it can be the telephone, multimedia, integrated computer, $\mathrm{TV}$, and more. (b) Cool location, the user leaders are looking for new and different things. For example, it can be creating a niche or subsequent big things such as Korean food with an innovative flavor, smart car, and so on. (c) White location is where new opportunities grow, even though it has not been exploited such as innovative interactive retail or wallet without cash. (d) The black place is where sellers and key players are removed from the film industry for traditional photography and car manufacturers, and so on. This may sound impractical or far from the market habits. It explains the morphology of all e-commerce markets today (Fisk, 2008).

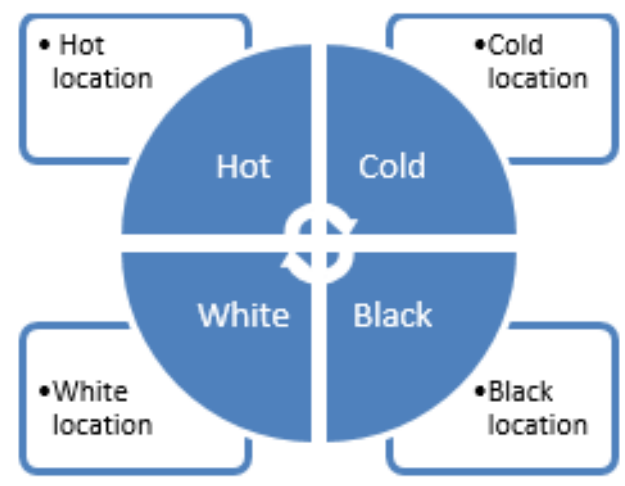

Figure 10 Location Sharing in E-Commerce and Innovation Strategies

The market is now more subtle than ever and is influenced by external changes. Some of the highgrowth markets that deserve to be explored may require strong offers and solutions such as possibly in partnerships with stronger brands and distributors.

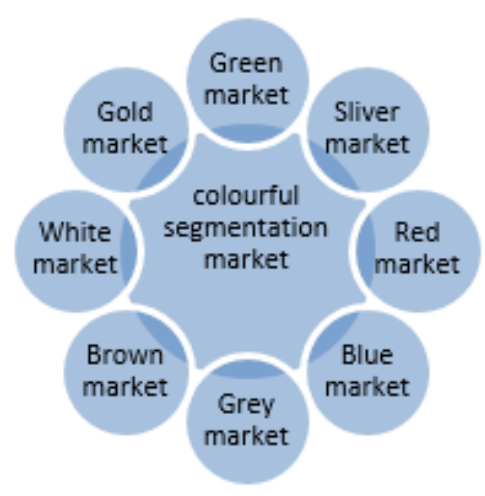

Figure 11 Colorful Segmentation Market 
Figure 11 describes the colorful segmentation markets for Blibli.com. The green market is the birth of a conscientious consumer who wants to do everything right. Although some are very concerned about the future of the planet and its environment, many are involved in issues related to local issues, such as security and education, and personal issues such as happiness. The silver market is the baby boomers who reach their heyday. The red market is the former Soviet Union states in Eastern Europe. It may still have some bad images, but most of those countries now are the part of the European Union. Those are countries with booming economies and entrepreneurs. The blue market is when the east may be a new west. South became the new north. From southern Africa to Brazil, India to Dubai, the south is now climbing from a low-cost manufacturing economy to a technologydriven power. Those are driven by business knowledge and high personal ambition. Then, the gray market is for people who are enthusiastic about high-tech technology. They are the hunters of any gadget. Geoffrey Moore calls them early adopters, but often they are just different markets. They want to do things differently from their everyday gadgets, whether it is for personal productivity or it makes them look cool (Moore, 2015).

Next, the chocolate market is fashion trends. Following the fashion cycles, it also reflects a plan for authenticity. The white market is a low-cost market. For example, the airlines are driven by the needs of middle-class society, but it also reflects people's fondness for cheap things. Last, the gold market or the luxury goods market is probably the fastest growing market in the world. Interest for luxury brands across Asia is booming, as well as the aspirations of key markets throughout the western world, even by those who cannot afford it.

In Figure 10 and Figure 11, it can be seen that strategy is a very important factor in developing a company that has an e-commerce base. This should be supported by other factors in running the process. 7S's Mckinsey can support this and can be explained as follows. Figure 10 is a Structure-Style-Systems innovation that must be done by Blibli.com, where the location structure is an important thing that must be determined in advance in expanding the e-commerce market. Blibli.com needs a precise location-a different style in the face of competition and a more precise targeting system. In here, Blibli.com will be able to determine the right Structure-Style and System dimensions, such as general-aggressiveness and capability. General means showing many incompetition competitors in the e-commerce industrythis includes also potential competitors who have first had a market location. In the aggressiveness section it concerns the extent to which Blibli.com competitors are implementing their location position. Blibli.com should be careful to see this because a competitor with a highly creative and effective strategy will be far more dangerous than a competitor group without a creative strategy. In the final section, capability, it is about the financial capacity of the location. Blibli. com should assess the situation of a location with its financial strength and what products can be sold in that location.

Figure 11 is a Strategy-Staff-Skills innovation that after location is determined, market segmentation needs to be done more specifically. In the Staff and Skills section, Blibli.com needs reliable human resources to support the expansion, and reliable sales to support massive sales. The strategy must support the vision and mission set by Blibli.com. Some staff and skills specifications should also be determined by Blibli.com to face this global competition. Sales person is the key strength in dealing with it, that the sales person is divided into four important types. (1) competitor-type has great ambition to win and wants satisfaction can defeat rival. If it connects with a segmentation strategy, this type will expand rapidly. (2) The ego-driven type is the best acknowledged, regardless of the others. This is a highly unacceptable type of work for e-commerce companies. This type causes problem. (3) Type achiever is a very rare type. They will expand the market segment of Blibli.com slowly. However, they always manage to achieve the goal correctly. This type is highly recommended to work in Blibli.com. (4) Service-oriented type has the power to build communication very well. They will help Blibli.com in maintaining the market segment that has been built, building, and expanding more segments of new products offered by Blibli.com.

\section{CONCLUSIONS}

Blibli.com is an e-commerce company that has a very innovative CRM. Using The 7 stages of McKinsey, the structure, system, and strategy can be seen especially on infrastructure owned by Blibli.com. It can support the competition among e-commerce companies. The vision and value of Blibli.com can sustain the company to move more competitive. In the skill, staff, and style, Blibli.com has capable human resources in meeting the needs of the company's resources.

Furthermore, from the results of the analysis, the researchers create a framework to segment the market, so that Blibli.com can compete and increase profits better. As a suggestion, Blibli.com can expand its e-commerce company to a wider range using a close category strategy. It is determined by more innovative business or type products, applications, and adjacent consumers (segments need to be pre-determined with the target of the geographical position), and the adjacent ability (management and process skills and assets are used maximally) (Fisk, 2008). 


\section{REFERENCES}

Anwar, J., Shah, S., \& Hasnu, S. (2016). Business Strategy and Organizational Performance: Measures and relationships. Pakistan Economics and Social Review, 54(1), 97-122.

Fisk, P. (2008). Business genius: A more inspired approach to business growth. UK: Capstone Publishing Ltd.

Gamayanto, I., \& Esti Nilawati, F. (2017). Pengembangan dan implementasi dari wise netizen (e- comment) di Indonesia. Techno.Com, 16(1), 80-95.

Hossain, S., Sohrab, K., Jamshid, N., \& Mahmood, A. (2012). Alignment in the organizations strategy window (concentration on business strategy and operations strategy). African Journal of Business Management, 6(51), 12016-12022. https://doi. org/10.5897/AJBM12.523

Ilieska, K. (2013). Customer Satisfaction Index-as a base for Strategic Marketing Management. TEM Journal 2(4), 327-331.

Lundberg, F. (2012). Mechanistic-organic organizations-An Axiomatic Theory: Authority based on bureaucracy or professional norms. International Journal of Scholarly Academic Intellectual Diversity, 14(1), 7.

Lunenburg, F. C. (2012). Organizational structure: Mintzberg's framework. International Journal of Scholarly, 14(1), 1-8.

Madu, B. C. (2012). Vision: The relationship between a firm's strategy and business model. Journal of Behavioral Studies in Business, 5, 1-9.
Mcfarlane, D. A. (2013). The strategic importance of customer value. Atlantic Marketing Journal, 2(1), 62-75.

Moore, G. A. (2015). Zone to win: Organizing to compete in an age of disruption. Diversion Books.

Ramseook-Munhurrun, P. (2010). Service quality in the public service. International Journal of Management \& Marketing Research (IJMMR), 3(1), 37-51. https:// doi.org/10.1017/CBO9781107415324.004

Ravanfar, M. M. (2015). Analyzing organizational structure based on 7s model of McKinsey. Global Journal of Management and Research: A Administration and Management, 15(10), 6-12.

Rigby, D., \& Zook, C. (2002). Open-market innovation. Harvard Business Review, 80(10), 80-93.

Soliha, E. (2008). Analisis industri ritel di Indonesia. Jurnal Bisnis dan Ekonomi, 15(2), 128-142.

Tan, S. S. D. (2013). Kajian customer relationship marketing dalam bisnis ritel. Jurnal Ilmiah Mahasiswa Manajemen, 2(2), 1-7.

Tutupary, S. E, \& Aldianto, L. (2014). The benefits of management information system on the effectiveness and efficiency on the online business. Journal of Business and Management, 3(8), 835-849.

Wang, G., Abdul, H., \& Nurul, F. A. (2017). Comparative analysis of e-commerce and social media based trading in Indonesia. In IOP Conference Series: Materials Science and Engineering (Vol. 237, no. 1, pp. 012028). IOP Publishing.

Wardhana, A. (2016). Viral marketing determinants of top online shop brands in Indonesia. Mimbar: Jurnal Sosial dan Pembangunan, 32(1), 25-30. 